\title{
Arborescences
}

Revue d'études françaises

\section{Re-Visualizing the Map in Guy Delisle's Pyongyang}

\section{Nancy Pedri}

Numéro 4, novembre 2014

Le dispositif texte/image

URI : https://id.erudit.org/iderudit/1027434ar

DOI : https://doi.org/10.7202/1027434ar

Aller au sommaire du numéro

Éditeur(s)

Département d'études françaises, Université de Toronto

ISSN

1925-5357 (numérique)

Découvrir la revue

Citer cet article

Pedri, N. (2014). Re-Visualizing the Map in Guy Delisle's Pyongyang.

Arborescences, (4), 99-114. https://doi.org/10.7202/1027434ar

\section{Résumé de l'article}

Cet article se penche sur les cartes introduites dans le texte de Guy Delisle : Pyongyang. En exploitant les manipulations cartographiques mises en oeuvre par cet auteur, mon étude cherche à montrer que les cartes géographiques introduites dans cette bande dessinée sont destinées à mettre en évidence, voire à accentuer les stratégies qui ont participé à sa production en tant qu'oeuvre de fiction. d'utilisation que vous pouvez consulter en ligne.

https://apropos.erudit.org/fr/usagers/politique-dutilisation/ 


\title{
Re-Visualizing the Map in Guy Delisle's Pyongyang
}

\author{
Nancy Pedri. Memorial University of Newfoundland
}

\begin{abstract}
I examine the use of maps in Guy Delisle's comic Pyongyang. Focusing on the overt manipulation of cartographic techniques, I show how the cartoon map attains accuracy not by hiding, but by accentuating the fictional techniques that went into its making.
\end{abstract}

\section{Cartoon Maps}

Pyongyang is Quebecois comics artist Guy Delisle's travel memoir of his two-month stay in Pyongyang, capital of North Korea, where he went to supervise a French animation project that was outsourced there. As in his other travelogues, Burma Chronicles, Shenzhen and Jerusalem, Pyongyang opens with a grey sketch of a world map drawn on the upper portion of an otherwise white page (Figure 1). A focal box marks out a small section off to the right end of the world map delineating an area that is reproduced in a much larger scale on the bottom half of the page. The slightly more detailed section is of North and South Korea with their capital cities, Pyongyang and Seoul, named and located on the

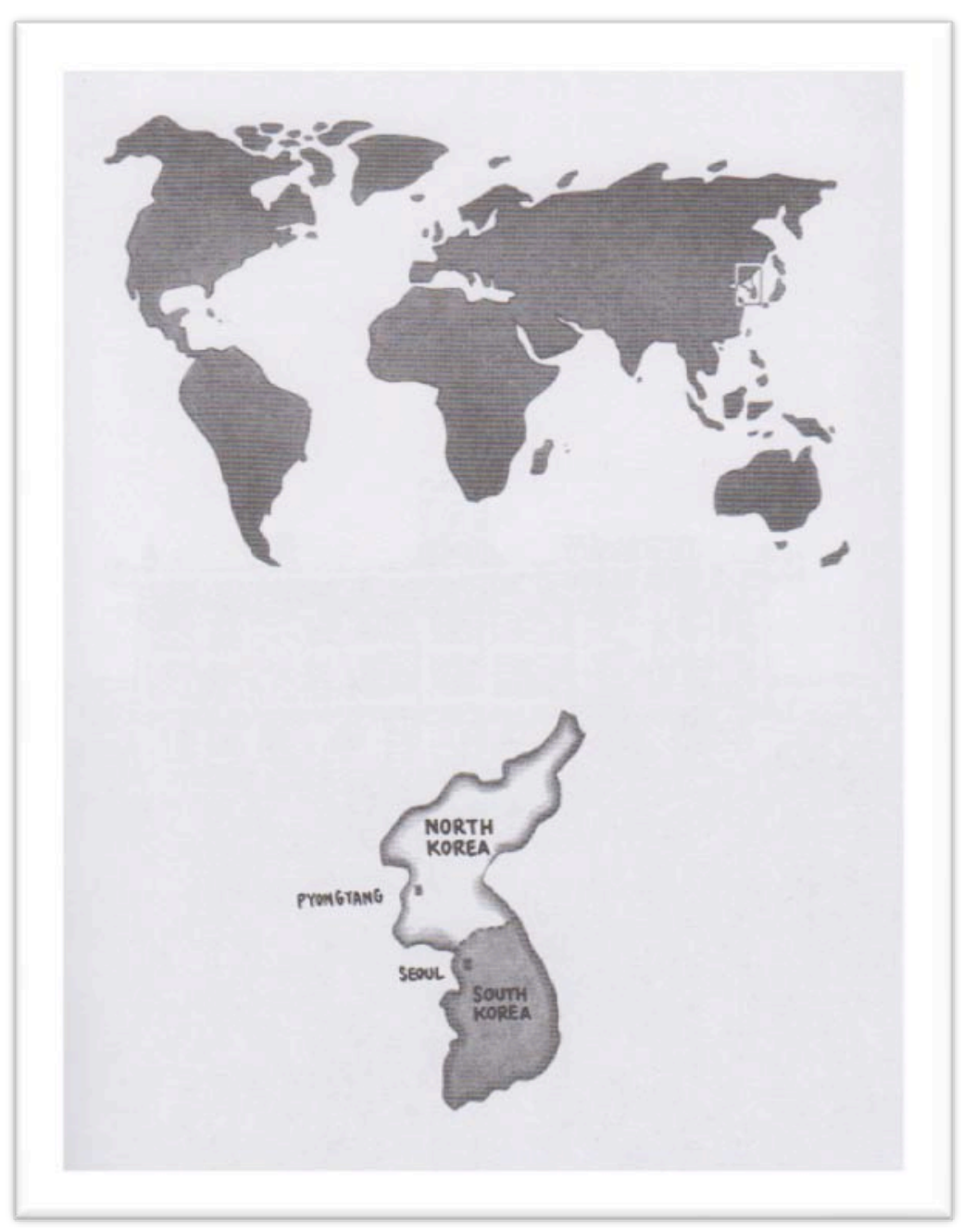
map with a small grey square.

North Korea is the only country or parcel of land on both the world map and the larger scale map that is white with grey shading demarcating its border. The use of white to demarcate a piece of land on an otherwise grey map announces the importance of this specific geographical location in the text 
that follows. The map thus operates as a literary device that directs reading practices; it both shows and makes seen what needs to be seen.

Subtle and not-so-subtle focusing devices such as the one found in the introductory map abound in the maps Delisle draws into his account of everyday life in Pyongyang: while some maps incorporate a white rounded rectangle to delineate a particular geographical space, others include cartoon arrows that direct reading practices. These and other reading directives break away from standard map-making practices that encourage and rely on the absence of any authorial traces in order to secure the type of detached authority maps are appreciated for. Maps, Denis Wood argues, are powerful representations of actual geographical places as long as the author- "and the interest he or she unfailingly embodies" (1992: 70) — is not readily perceived within them. When the author "is in plain view, it is hard to overlook him, hard to see around her, to the world described, hard to see it ... as the world. Instead it is seen as no more than a version of the world, as a story about it, as a fiction: no matter how good it is, not something to be taken seriously" (Wood 1992: 70, emphasis original). Although all maps are a "manipulated form of knowledge" (Harley 1988a: 277), the use of a standardized style and the inclusion of certain types of content that have become so common as to appear natural help secure the author's transparency, a transparency needed for maps to be taken as accurate renditions of actual space.

Cartoon maps, unlike their technical counterparts, are hard pressed to render invisible their author and, by extension, hide his or her personal vision. Besides an absence of standardized cartoon drawing practices for the charting of land, readers of comics are acutely aware that what they are reading is a representation fraught with a particular subjectivity, a picture that someone has arranged, compiled, framed, in short, coded. This awareness is directly linked to the handcrafted quality of cartooning. Comic journalist Joe Sacco sees "cartooning [as] an inherently subjective medium" since "[a] cartoonist assembles elements deliberately and places them with intent on a page" (Sacco 2012: xi-xii). Comics openly operate under the pretense that all that is presented visu-ally and verbally was "transformed through somebody's eye and hand" (Wolk 2007: 118). Since the "formal grammar [of comics] rejects transparency and renders textualization conspicuous" (Chute 2008: 457), since "everything in [its] represented world is very overtly as if" (O'Neill 1994: 99), the cartoon map's portrayal of place is openly caught up in the cartoon image's constructed and inter-pretative quality. ${ }^{1}$

${ }^{1}$ See Marion, who argues that "le but du récit est de conquérir les esprits en tentant de faire oublier son statut de repré-sentation, mais le media et les moyens d'expression que [la bande dessinée] mobilise font résistance" (1993a: 78). See also Verano, who describes the narrative universe of comics as the world of the fictional signifier (2006: 326); Versaci who argues that "the comic book projects unreality to some degree because every comic book is a drawn version of the world and, therefore, not real" (2007: 12); and Round (2010), who supports 
Even a cursory consideration of the visual properties of Delisle's cartoon maps confirms that the cartoonist's hand is everywhere, so to speak. His maps adopt a number of discursive strategies-appraisive, evaluative, persuasive strategies — to present a very particular view of North Korea. Once Delisle's maps are understood to be narratives conditioned by his agency, it becomes necessary to ask how some of the multimodal narrative strategies and conventions operative in Pyongyang's use of maps impart to readers the cartoon map's special reality, special in that it attains accuracy with respect to the external reference world by accentuating, and not hiding, its own fictional techniques. How do deliberate cartographic forms of manipulation-from concealment to abstraction, omission to highlighting-work toward securing the type of accuracy desired in maps, an accuracy that is operative even when maps are included in the literary universe of comics? Can it be that with cartoon maps an accurate portrayal of reality (as much as that is possible) is necessarily and openly tied up with inventiveness and all that has to do with storytelling?

\section{Mapping More than Space}

Pyongyang's first chapter makes readers privy to the protagonistnarrator's, Guy's, initial impressions of the country, impressions that are delivered alongside strict rules in a "booklet of travel tips" (Delisle 2012d: 4) about hygiene, travel and other important details such as what is allowed and prohibited in the country. With a heavy sense of his status as foreigner, Guy begins his journey of discovery with the obligatory homage that has to be paid to a 22-metre high bronze statue of Kim Il-Sung, the country's president despite his death in 1994. He also details his arrival at the cold and impersonal hotel located on a small island close to Pyongyang's downtown core, and offers up an overview of the working conditions at the animation office where he will be working. The narrative comments presented in rectangular text boxes are in Guy's personal voice: he stops on the dark airport, the guides that accompany each foreigner without respite, and the deserted hotel bar. ${ }^{2}$ Visually, the rectangular comic panels come together to portray a similarly bleak physical landscape: a flat, monotonous expanse of land with large streets devoid of people, buildings and cars and a cityscape with few cars, some people walking the streets and political propaganda displayed on the façade of buildings.

this view in her examination of the blurring of fact and fiction in Alan Moore and Eddie Campbell's From Hell.

${ }^{2}$ Mikkonen proposes an analysis of Pyongyang's use of two first persons, "the narrating voice and the experiencing self who is seen" (2008: 313). 
The introductory chapter offers up for consideration Guy's initial impression not only of North Korea's physical landscape, but of its psychology as well. Guy's comments about place are interspersed with pointed critique that hints at North Korea's mental makeup. Guy is by far not a neutral observer: he is quick to determine that his hotel room is "just like they like them in Asia" (Delisle 2012d: 9) or that "the [Scientific and Educational Film Studio of Korea (SEK)] might have been intended to educate the masses, but these days it's used to attract foreign currency, most of it in French" (Delisle 2012d: 11). The country's mental constitution poignantly comes to light through Guy's terse verbal and visual commentary. For instance, a large and strategically placed panel showing Guy's new "little family" includes two stony-faced North Korean men looking straight out of the panel and Guy smirking while looking at the two men (Figure 2). Each man holds a sign with two hands as a criminal would in a police line-up that specifies their new family relations: "Comrade Guide", "Comrade Translator" and "Foreign Capitalist". Just as "Comrade" speaks to how Guy views his new family and to how they view themselves, "Foreign Capitalist" speaks to how the North Koreans see Guy as well as to how Guy views himself within this new configuration. This complex mental landscape is filtered through Guy-the-narrator who writes and draws his person into the story.
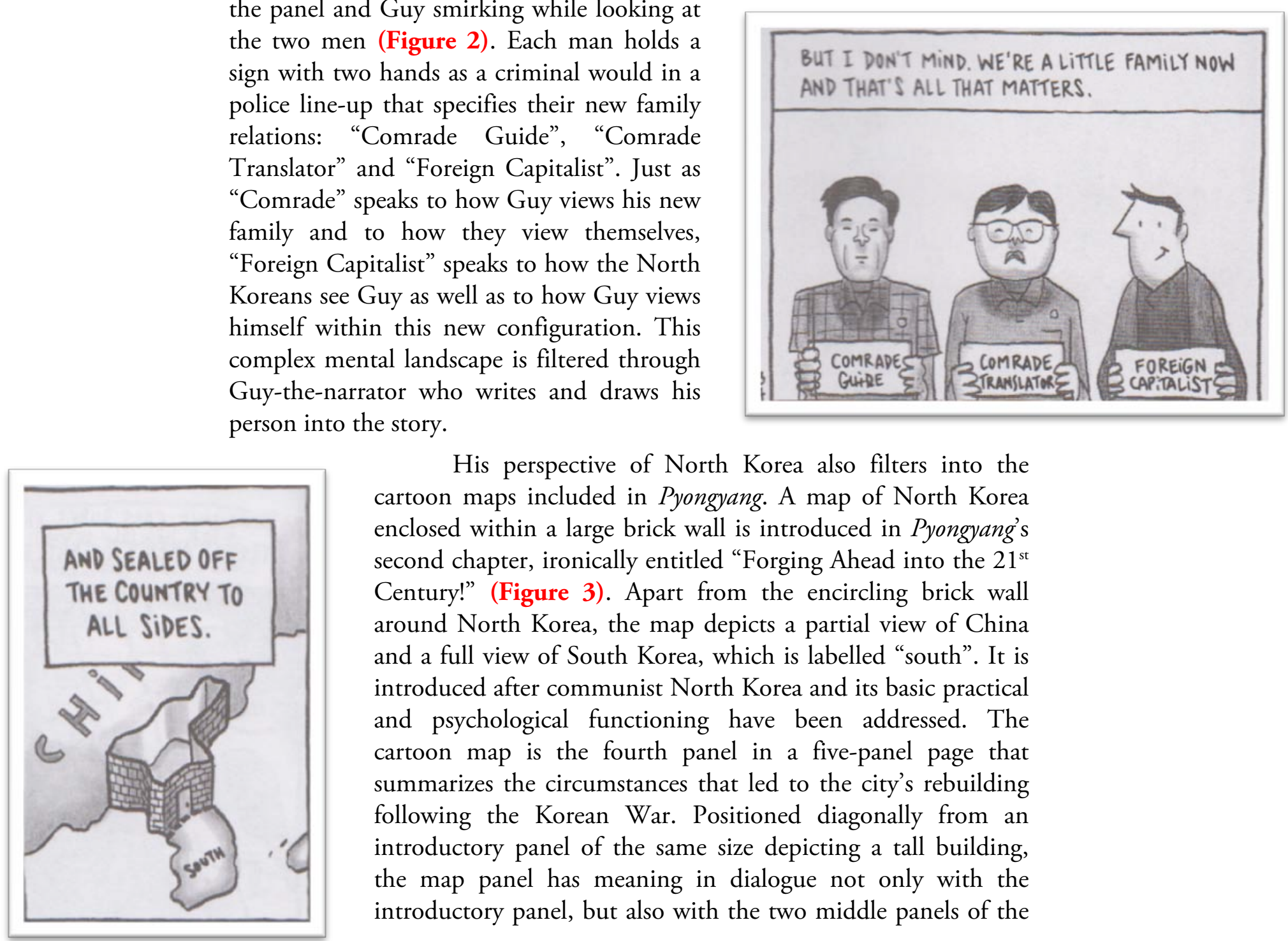

His perspective of North Korea also filters into the cartoon maps included in Pyongyang. A map of North Korea enclosed within a large brick wall is introduced in Pyongyang's second chapter, ironically entitled "Forging Ahead into the $21^{\text {st }}$ Century!" (Figure 3). Apart from the encircling brick wall around North Korea, the map depicts a partial view of China and a full view of South Korea, which is labelled "south". It is introduced after communist North Korea and its basic practical and psychological functioning have been addressed. The cartoon map is the fourth panel in a five-panel page that summarizes the circumstances that led to the city's rebuilding following the Korean War. Positioned diagonally from an introductory panel of the same size depicting a tall building, the map panel has meaning in dialogue not only with the introductory panel, but also with the two middle panels of the 
four-panel series (Figure 4). ${ }^{3}$ The cartoon map panel closes a set of two symmetrical rows, the first row comprised of a small panel followed by a panel roughly double its length and the second row comprised of the same size and number of panels but arranged in the reverse order. The first small panel of the four-panel series is a close-up of a new building against a white sky with a text box specifying that "it's all new" (Delisle 2012d: 26). A similar white space on the bottom portion of the small map panel in the second row demarcates the water surrounding China, North Korea and South Korea.

These two small light coloured

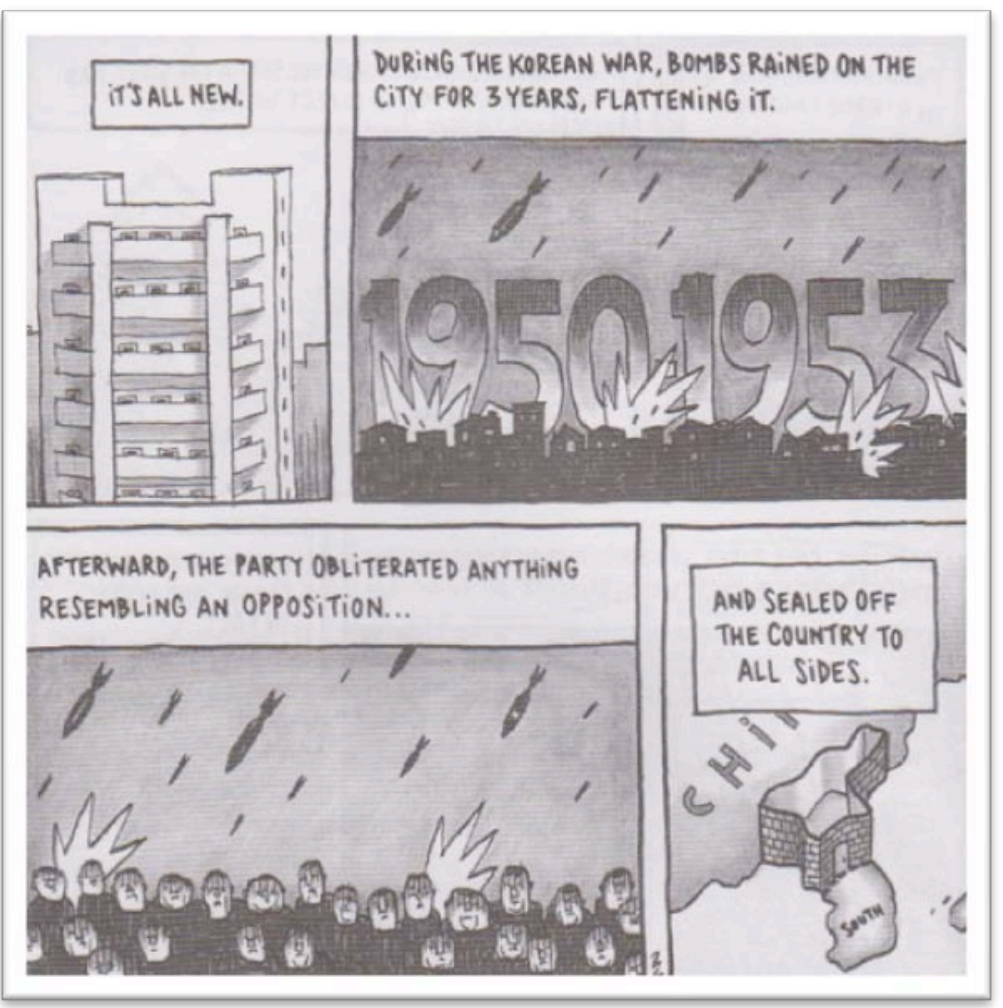
panels, with their depictions of light-grey walls and white skies or water, contrast with the two longer and darker panels they frame. Both long panels adhere to a similar colour scheme with dark grey across the top that darkens into black toward the bottom of the panel. The bombs that "rained on the city for 3 years" (Delisle 2012d: 26) in the first long panel are shown in the following panel as raining down on a group of people dressed in dark black clothing. The text box specifies, "afterward, the party obliterated anything resembling an opposition..." (Delisle 2012d: 26). The text's assertive comment is completed in the map panel where a text box positioned overtop the letters and area indicating China explains, "and sealed off the country to all sides" (Delisle 2012d: 26). In these panels, a parallel is suggested between the buildings that were flattened out during the Korean War (1950-1953), the people who were forced into conformance following the war and the country that was blocked off from all others.

The contrast between the set of panels and their symmetrical alignment brings readers to read additional stories within the markings of each comic panel. Links between Pyongyang's new buildings and the devastating destruction of the Korean War to both place and people are extended into notions of a new state configuration. The suggestive

${ }^{3}$ Mikkonen proposes an analysis of Pyongyang's use of two first persons, "the narrating voice and the experiencing self who is seen" (2008: 313$)$. 
juxtaposition of the four symmetrical panels makes it possible to see within the cartoon map's wall a reflection not only on place, but on collective identity as well. Within this cartoon rendition of an interstate map, the postwar condition of North Korea is linked to that of a fortified town, hence drawing forth at once notions of secrecy and enslavement. The brick wall communicates visually the government's sealing off of the country from neighbouring countries and all other foreigners, but it also suggests that the very same government imprisons North Korea and its people within its boundaries. The cartoon map of North Korea, with its blatant modification, thus relates back to and confirms a narrative comment made in the introductory chapter. In a long panel showing Delisle lying on his bed after his first night in the hotel, an uncharacteristically lengthy text box specifies: "North Korea is the world's most isolated country. Foreigners trickle in. There's no internet. There are no cafés. In fact, there's no entertainment. It's hard to even leave the hotel and meeting Koreans is next to impossible" (Delisle 2012d: 10). In both this verbal narrative comment and the comic map, the isolation of the country is superimposed on the (forced) isolation of the people. The map thus extends beyond the charting of place to comment on the North Korean collective identity as well as the inconsistencies existent in the country's government policies. Delisle thus breaks from map conventions, including a wall around a piece of land, to indicate that the North Korea mapped out in Pyongyang is not just a geographical space, but a living space shaped by people and the institutions that govern them.

\section{Mapping My World}

In his reflection on comics journalism, Sacco explains that " $[t]$ he cartoonist draws with the essential truth in mind, not the literal truth, and that allows for a wide variety of interpretations to accommodate a wide variety of drawing styles" (2012: xii). As argued above, the cartoon maps included in Pyongyang incorporate the protagonist's subjective understanding of his new environment and its people not only by way of the expressive use of the graphic line, but also across the cartoon page layout and the map's position within it. The map thus serves as a means of spatial containment as well as a systematic organization of Guy's perceptions. In Pyongyang's cartoon maps, "[t] he discourse of the territory is interwoven with many threads of the geographic and emotional imagination, as well as of economic and social realities", as Itala Vivan argues in another context (2000: 56). By drawing the maps in the same cartoon style as all of the other comic panels or images that comprise Pyongyang, Delisle openly embraces the subjective and the imagined in his renditions of place and how it intersects with a political and social climate. 


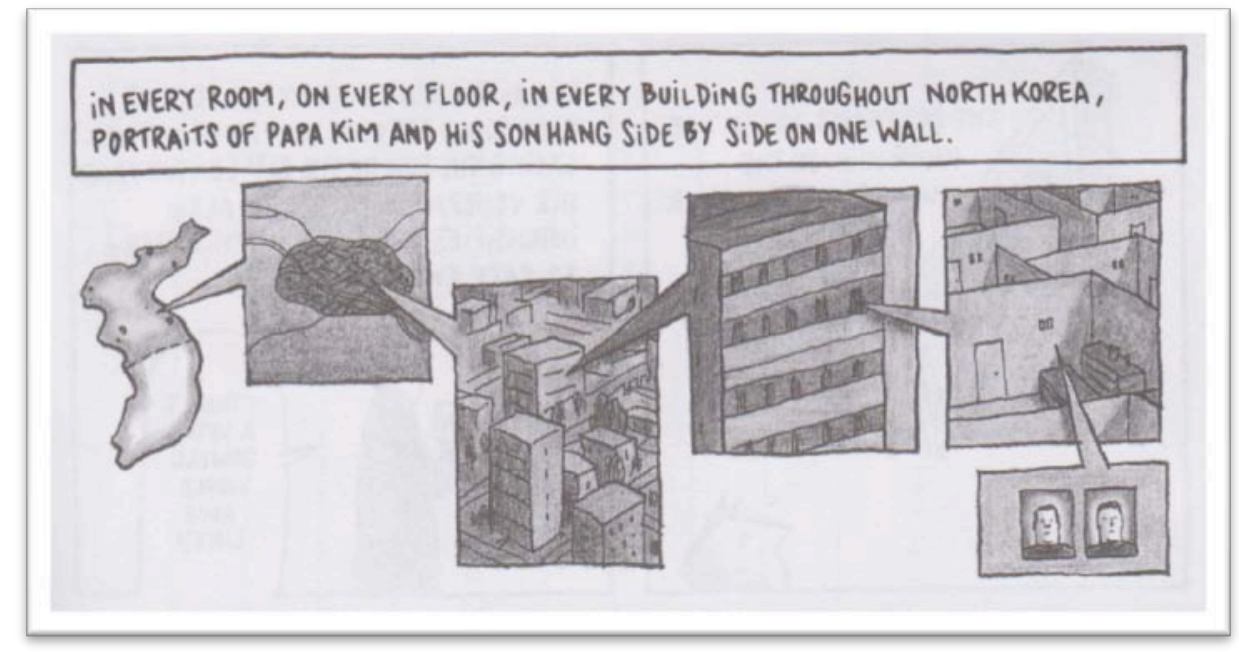

In comics, "style [is] a narrative choice-and not simply a default expression" (Chute 2010: 146). Comic critics have stopped on the "obsessive presence of style (a term which should be understood here as synonymous with a specific graphic writing) in any drawn narrative" to argue that a "drawing cannot be separated from the hand of a specific enunciator" (Groensteen 2010: 4). ${ }^{4}$ Indeed, every comic has its own particular pictorial and lettering style that "encourage readers to see the story as the author's personal expression" (Versaci 2007: 44). ${ }^{5}$ And although much can be said about how that style triggers recognition and appreciation of a certain artist's work, what is impor-tant to accentuate here is that style actually presents readers with a particularly personal vision of what is remembered as having been experienced. Style, then, speaks not so much to what is seen and remembered, but rather to the subjective interpretation of what was seen and remembered or what some call the "'cartooning as interpretation' effect" (Wolk 2007: 121). So, to include maps that are consistent with the dominant visual cartoon style in a graphic travel memoir is to assert that the subjective filters into each aspect of the narrative. Like all drawings, the map "reflects the vision of the individual cartoonist" (Sacco 2012: xii).

In Pyongyang, the cartoon map is a highly self-reflexive image, one that accommodates our eye-witness narrator and his perceptions into its lines. When the introductory large-scale map of North and South Korea is once again reproduced in the narrative, it is presented as the image out of which begins a series of picture narrative boxes (Figure 5). In order, they depict a

\footnotetext{
4 See Marion (1993b) who divides comic's visual track into two levels of enunciation, graphiation and monstration, to account for the workings of graphic style; and Wolk (2007) who stops on how cartooning can be read as a metaphor for the subjectivity of perception.

5 Delisle's drawing style oscillates between recognizable people and buildings and dark, shaded, indescript renditions of place and people. This may be considered an effective way of showing readers how much of what he sees and experiences in North Korea is "strange... very strange..." (Delisle 2012d: 32), that is to say, beyond comprehension.
} 
general view of an unnamed city; a close-up of some of its buildings; a detailed section of one particular, but unidentified building; a room in that building; and eventually the portraits of Kim Il-Sung and Kim Jong-Il hung side by side on one of the room's walls. The picture narrative box series is accompanied by a narrative text box that specifies: "In every room, on every floor, in every building throughout North Korea, portraits of Papa Kim and his son hang side by side on one wall" (Delisle 2012d: 29). The series is a visual transcription of Guy's general observation of the ubiquity of the two portraits, a general observation, however, that is laden with critique. The map is the first image on a comic page where Guy's personal commentary abounds: he sarcastically notes that the portraits obviously do not hang "in the shitters" and that "it's always the same head at the helm" (Delisle 2012d: 29). A two-headed, one-bodied leader at a podium marked with a sign that reads "the world's only communist dynasty" (Delisle 2012d: 29) accentuates Guy's sarcastic tone, as does the use of verbal repetition in the narrative text boxes throughout the comic page. And, if the narrator's tone coupled with images at once humorous and poignant in their critique are not enough to signal his subjectivity, the comic page ends with Guy sitting on a couch looking up at two framed wall hangings, legs crossed, narrating how his “coffee breaks lead to a few more observations" (Delisle 2012d: 29). Although the familiar portraits cannot be seen in full, it is obvious that they are what is intended by the partial view of the frames. Delisle's observations are tainted by his own imaginative filtering. This is further supported by the fact that the city or town to which the first picture narrative box points to is a place that the narrator-protagonist has never visited: it is located on the coast, opposed to Pyongyang. So, although the narrative is based in personal first-hand experience, it is equally grounded in Guy's subjective imagination that filters all of the observed details of life in North Korea that are presented both verbally and visually in Pyongyang.

Critics have argued that cartography, more than any other geographic enterprise, pushes land into meaning through authorial acts of personal intervention as well as personal inscription. Denis Wood, for instance, is of the opinion that "the knowledge [a map] embodies is socially constructed, not tripped over and no more than... reproduced" (1992: 18, emphasis original). Wood does not dismiss the map's appeal to reality, an appeal rendered particularly strong by the map's adherence to mimetic models of representation (see Huggan 1989: 116). Instead, he works hard to argue that the reality represented in the map is one that has been framed and thus crafted by a particular vision of the world. It is the correlation between the map's appeal to reality and notions of objectivity, accuracy, transparency and neutrality-notions that have guided the understanding of maps for centuries - that Wood contests. By exposing maps as social constructs that “necessarily embody their author's prejudices, biases and partialities (not to mention the less frequently observed art, curiosity, elegance, focus, care, 
imagination, attention, intelligence and scholarship their makers bring to their labor)" (Wood 1992: 24), Wood posits the map as a carefully crafted story, a "controlled fiction" as Phillip Muehrcke puts it (1978: 103), that conveys knowledge of both the land charted and the cartographer who did the charting. So, although posing as and often passing for objective representations of land, maps tell stories that are shaped by a particular version or knowledge of the world.

The difference between standard maps and those that are an integral part of Pyongyang's storyworld lies in how the cartoon map actually draws attention to its attempt to make sense of and relate certain aspects of North Korea. On the one hand, Delisle's maps function as other maps do, providing "a source of information but, more importantly, [...] challeng[ing] the reader to match his / her experience of the text with the 'reality' represented on the map" (Huggan 1994, 21). However, the open tampering with the standard mode of cartographic representation, the modifications to the map's surface, the introduction of a different shading pattern and of spots that indicate population densities, and the addition to it of a series of picture narrative boxes visually addresses the analytical enterprise that went into the map's making. Together, these indicators of the map-maker's vision draw notice to how maps are made to mean something in accordance to their author's particular agenda. They make apparent the thought process that went into the selection of the map's details and, in so doing, foreground its cartographic facts as openly caught up in Delisle's subjective reporting.

The cartoon map, which is as malleable as all cartoon images, thus presents another occasion for Delisle to draw himself into the story. Delislethe-cartoonist repeatedly factors into the narrative, not only as a perplexed character carefully observing his new environment, but also as graphic artist sitting at his desk sketching "the day's events on the right-hand page and writ[ing] a few notes on the left" (Delisle 2012d: 85). ${ }^{6}$ This visual and verbal note-taking, in a country where "[n]ot everything can be photographed" (Delisle 2012d: 5), is crucial in order to reach his goal of relating as accurately as possible what he witnesses first-hand. Unlike many other characters in Pyongyang, Guy is easily recognizable with his pointed nose, small eyes and dark short hair. Rarely a mere shadow in the background, he visually dominates Pyongyang's narrative space, with numerous cartoon panels depicting him in his daily tasks - reading in bed, taking the elevator, sitting at his desk both at work and in his room, listening to his radio, lying in bed thinking, and so forth. Over and over again, Delisle casts himself as a somewhat naïve character who observes, with a growing sense of puzzlement,

${ }^{6}$ Delisle took notes during his stay in North Korea and then molded them into a book while in Ethiopia (Delisle 2012a: n.p.). 
how people live. ${ }^{7}$ Of his trip to communist North Korea, he wondered if there is "something wrong and the people are really proud to fight and all that...", only to realize that " $[\mathrm{t}]$ hey were just living, that's all" (Delisle 2012a: n.p.). It is this living that Delisle sets out to convey to readers. "When I do these books", he says, "I have the feeling I'm writing a long postcard to my mom. Except now I write for my readers. And I really feel the reader sitting next to me and I say, 'Let's go over here, there's a great place I want to show you'” (qtd. in Köhler 2012: n.p.). The additions and modifications to the maps of North Korea included in Pyongyang are indicative of Delisle's desire to show readers what he sees and how he sees it, especially if one considers that mapping, as Wood reminds us, "is a way of making experience of the environment shareable" (1992: 79, emphasis original).

\section{Mapping the World of Maps}

As Guy becomes more familiar with North Korea and its social climate, as his vision matures, his critique of the regime becomes more and more poignant. A chapter roughly mid-way through Pyongyang is devoted to the Juche tower-Juche being the idea of "self-reliance" that "is the official ideology of the regime" (Delisle 2012d: 72). It opens with Guy reflecting once again on the portraits of Kim Il-Sung and Kim Jong-Il that are reproduced on official pins worn by every North Korean. After admitting that "it took [him] a moment to figure [...] out" that they were official pins (Delisle 2012d: 66), Guy provides a brief history of the ideology of Juche. He then turns his (and his readers') attention to the propaganda fueling "the idea of Juche, the source of life that invigorates the spirit of all people, transcending latitude and longitude" (Delisle 2012d: 73) to ask, even if only silently, if North Koreans "really believe the bullshit that's being forced down their throats?" (Delisle 2012d: 74). Without much hesitation, he comes to the conclusion that "they live in a state of constant paradox where truth is anything but constant" (Delisle 2012d: 75), a conclusion reinforced by a silent panel depicting a Korean wind-up doll with a wind-up key provocatively protruding from its head and another from its back to suggest that both the minds and the actions of North Koreans are fully dictated and controlled by the regime (Figure 6).

\footnotetext{
${ }^{7}$ In no way am I suggesting that Delilse arrived in North Korea without any preconceived ideas about its social climate. Indeed, he admits to have done some research on North Korea before experiencing it firsthand (Delisle 2012c: n.p.).
} 


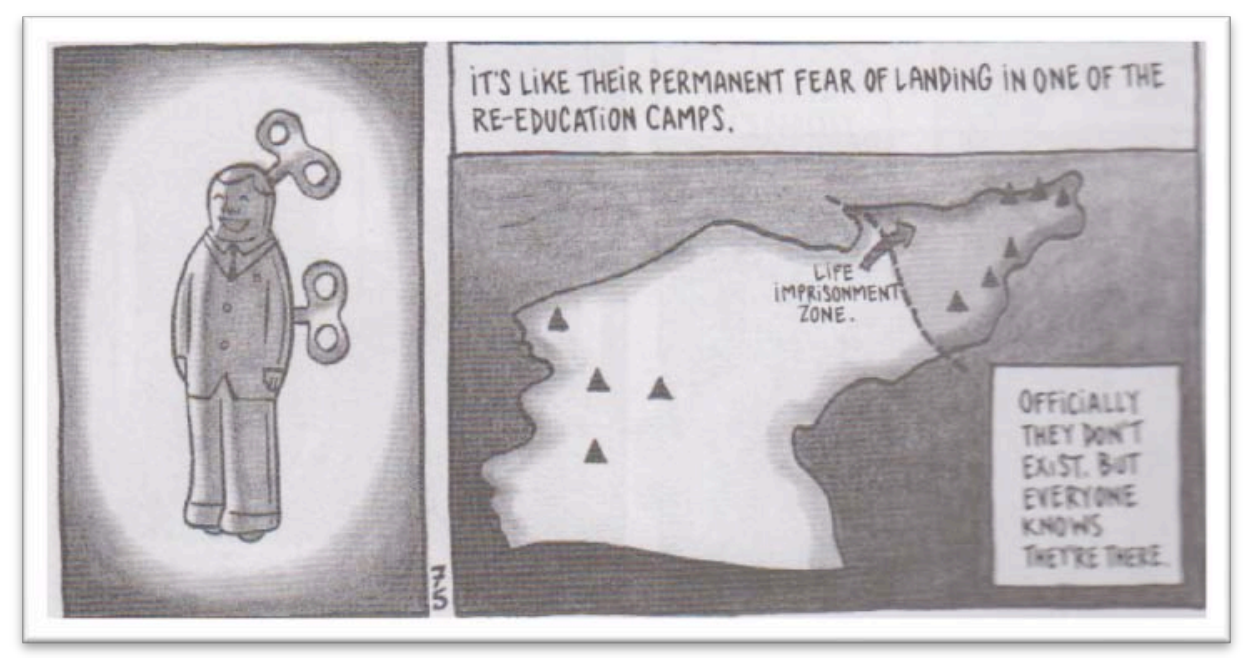

Tellingly, another modified map of North Korea is presented in the following panel. It visually speaks to Guy's reflections on how North Koreans are made to embrace a life full of contradictions and governed by inconstant truths. The two narrative text boxes that are part of the map panel (along with the wind-up doll silent panel that introduces the two-panel row) draw a strong parallel between the people and the place: "It's like their permanent fear of landing in one of the re-education camps. Officially they don't exist. But everyone knows they're there" (Delisle 2012d: 75). The map this text is coupled to is two-toned, with the very Northern tip of North Korea shaded in grey and demarcated by a dotted line boundary to which an arrow points with the specification "life imprisonment zone" (Delisle 2012d: 75). With this map, the last one of North Korea included in Pyongyang, Guy once again represents the territory in relation to what he perceives of the people and the social climate of oppression and inordinate display of power. In this instance, however, his personal visual filtering also fills in some gaps with respect to information that is glaringly obvious in the official maps as well as in the official narratives that give rise to those maps.

Maps, Cliff Ando argues, communicate effectively by "drawing out and bringing together certain details, while allowing others to recede into the background or remain altogether unex-pressed" (Ando 2008: 14). Delisle's cartographic revision that charts the unofficial, the not spoken, the hidden, actually draws attention to what the official maps do not show, but that nonetheless plays a vital role in the lives of North Koreans. By charting once again the North Korean territory with the addition of triangles to indicate reeducation camps and a dotted line to indicate the life imprisonment zone, the cartoon map functions to make up for an imposed silence and include aspects of reality that official mapping practices exclude. By doing so, however, it also serves to reveal and critique the lack of information that is part of standardized maps, such as the one reproduced at the beginning of Pyongyang. The inclusion of a map that so overtly disregards the codes of censorship and 
whose agenda is to make known that which is normally silenced, exposes the standard, official maps of North Korea as tools of propaganda concerned with propagating not so much geographical knowledge, but rather geopolitical knowledge. Svetlana Alpers, who approaches maps as artistic images (and not exclusively scientific ones), suggests that geography and, by extension, the cartographic chartings it authorizes, embodies a socially constructed knowledge of space: "What maps present is not land possessed but land known in certain respects" (Alpers 1983, 149). By drawing the life imprisonment zone and several re-education camps onto the map of North Korea, by mapping those spaces in North Korea that "officially [...] don't exist" (Delisle 2012d: 75), Delisle exposes maps to be socially constructed perspectives on the world, and not value-free, measurement-based, objective representations of a real place. ${ }^{8}$

It follows that by producing maps that re-visualize the North Korean territory, showing things that normally fall outside the strictures of cartography, Delisle exposes maps as not so much charting the world as it really is, but actually contributing to its social construction. As J.B. Harley argues of maps in general, "[both] in the selectivity of their content and in their signs and styles of representation, maps are a way of conceiving, articulating, and structuring the human world which is biased towards, promoted by, and exerts influence upon particular sets of social relations" (Harley 1988a: 278). ${ }^{9}$ Due to their obvious handcrafted quality, a quality that openly betrays the manipulation of place, Delisle's cartoon maps draw notice to the cognitive processes that Harley theorizes.

\section{Cartographic Revisualizations}

Throughout Pyongyang, Delisle adopts and adapts the language of maps to re-chart a place that through its very charting has remained somewhat unknown. He thus replaces the 'official' map that opened the book, the one that abided by the monolithic conventions of Western cartography, with other maps that share a cartographic discourse that is equally, but much more openly reaped with biases and judgements. Here, Deslisle overtly embraces rhetorical manipulation, fully aware of his role in the filtering of knowledge through representation. Indeed, his maps accentuate the representational economy of comics, the fact that in its universe there are few, if any, technological constraints to representation. Of comics, Delisle admits: "I love comics because they are so efficient. If I need to draw a little arrow, or a map, then I do" (2012b: n.p.).

${ }^{8}$ See Vivan who defines the map as "a representation, or rather a metaphor" (2000: 49).

${ }^{9}$ See also Harley (1990: 1-4), and Huggan (1989: 119). 
Although geographical and geopolitical facts are openly manipulated when translated into cartoon drawings, Delisle's maps do not forfeit authority. Instead, they bring together fact and fiction to impart to readers the truth of first-hand experience valued in travel literature. True to travel literature's promise to present an accurate, factual account of a particular journey and place, Delisle confesses, "I try to be just really precise and honest with what I've seen and-that's it. The reader can make up his own mind. He doesn't need me" (qtd. in Köhler 2012: n. p.).

And, indeed, throughout Pyongyang, the mark of location extends beyond geographical objectivity to include human dimensions-social, cultural, political dimensions. If nothing else, the reconfigurations of the North Korean map included in Pyongyang add pointed ideological messages and eyewitness interpretations to that which is officially recorded. Filtered through his own subjective perceptions, Delisle's maps are open statements about the world he experienced and the world his protagonist is experiencing. As a comic artist, he is not bound by sound cartographic principles that frown upon biases and distortions such as the manipulation of scale or content and deliberate omissions or additions. His cartoon maps are, in an important way, meaningful within the cartoon universe because of their use of distortion and bias; they are meant to provide a subjective perspective on the world they refer to.

What becomes apparent through Delisle's cartographic revisualizations is that maps are flexible, malleable, open to rewriting and manipulations. Indeed, Delisle redraws the map of North Korea several times throughout Pyongyang so to create a representation that begins to adjust that which is known of the country. Although he organizes the land according to his personal sense of space and an evaluation of what is significant insofar as it is charged with emotional and political import, his maps add significantly to North Korea's official narrative. As the protagonist's vision matures, as he learns more about North Korea, additional layers of complexity filter into the official map. The introductory map is therefore not discredited or rendered obsolete; instead, it gains in meaning every time it is revisited.

Engaging in deliberate acts of rewriting the official map of North Korea, the cartoon maps reproduced throughout Pyongyang thus support Gilles Deleuze and Félix Guattari's thesis that

[t]he map is open and connectable in all its dimensions; it is detachable, reversible, susceptible to constant modification. It can be torn, reversed, adapted to any kind of mounting, reworked by an individual, group, or social formation. It can be drawn on the wall, conceived of as a work of art, constructed as a political action or as a meditation. (1987: 12) 
In his overview of Deleuze and Guattari's model, Graham Huggan emphasizes that the map's adoption in literature and other arts entails a motion toward reconceptualising space where the official map is often parodied and/or subjected to irony. "[T] emphasis", Huggan specifies, "shifts from de- to reconstruction, from mapbreaking to mapmaking" (1989: 126). In Pyongyang's cartoon universe, the map certainly operates as a source of information that casts North Korea in a critical light but, more importantly, it openly, playfully adopts and adapts the official North Korean map so to challenge the official narratives that are held within it.

In addition, Delisle's cartographic revisualizations also challenge readers to adjust their understanding not only of the place that is being mapped, but of the processes that go into mapmaking itself. It follows that the authorial acts that go into the map's making are not confined to the mapmaking process. Instead, as Pyongyang reminds us, maps are meaningful also because they engage the reader's imaginative processes and general sense of the space that is charted. By giving North Korea a legibility that is missing in the world maps that most viewers are either familiar or comfortable with, Delisle recasts maps as images that can "engage both the imagination and the social preconceptions of their readers" (Harley 1988b: 58). As suggested above, maps in Delisle's Pyongyang do not so much chart the land through spatial containment or systematic organization, as engage the imagination of readers and trouble their notions of cartoon images, North Korea, and maps.

\section{Works Cited}

Alpers, S. 1983. The Art of Describing: Dutch Art in the Seventeenth Century. Chicago: University of Chicago Press.

Ando, C. 2008. "Driftwood to Google: How and What We Map: A Remarkable Exhibition in Chicago". TLS: 14-15.

Chute, H. 2010. Graphic Women: Life Narrative and Contemporary Comics. New York: Columbia Univer-sity Press.

Chute, H. 2008. “Comics as Literature? Reading Graphic Narrative”. PMLA 132 (2): 452-465.

Deleuze, G. and F. Guattari. 1987. A Thousand Plateaus: Capitalism and Schizophrenia. Trans. B. Massumi. Minneapolis: University of Minnesota Press.

Delisle, G. 2012a. "Cartoonist Guy Delisle on His Year in Israel and Creating Jerusalem: Chronicles From the Holy City". Interview with Mike Rhode. Washington City Paper. http://www.washingtoncitypaper.com/blogs/artsdesk/visual-arts/2012/04/25/meet-avisiting-cartoonist-a-chat-with-guy-delisle/. Feb. 6, 2013. Web.

Delisle, G. 2012b. "Guy Delisle: 'The challenge is not to explain too much". Interview by Rachel Cook. The Observer. http://www.guardian.co.uk/books/2012/may/31/guy-delislejerusalem-review-interview. March 7, 2013. 
Delisle, G. 2012c. "Guy Delisle - Tout le monde en parle". http://www.youtube.com/watch?v=0QsYVY_pdP4. March 5, 2013.

Delisle, G. 2012d. Pyongyang: A Journey in North Korea. 2003. Trans. Helge Dascher. Montreal: Drawn and Quarterly.

Groensteen, T. 2010. "The Monstrator, the Recitant and the Shadow of the Narrator". European Comic Art 3 (1): 1-21.

Groensteen, T. 2007. The System of Comics. Trans. Bart Beaty and Nick Nguyen. Jackson, MS: University Press of Mississippi.

Harley, J. B. 1990. “Cartography, Ethics and Social Theory”. Cartographica 27 (2): 1-23.

Harley, J. B. 1988a. "Maps, Knowledge, and Power". The Iconography of Landscape: Essays on the Symbolic Representation, Design and Use of Past Environments. Ed. Denis Cosgrove and Stephen Daniels. Cambridge: Cambridge University Press. 277-312.

Harley, J. B. 1988b. "Silences and Secrecy: The Hidden Agenda of Cartography in Early Modern Europe”. Imago Mundi 40: 57-76.

Huggan, G. 1994. Territorial Disputes: Maps and Mapping Strategies in Contemporary Canadian and Australian Literature. Toronto: University of Toronto Press.

Huggan, G. 1989. "Decolonizing the Map: Post-Colonialism, Post-Structuralism and the Cartographic Connection”. Ariel 20 (4): 115-131.

Köhler, N. 2012. "Guy Delisle: Stranger in Strange Lands". Macleans. http://www2.macleans.ca/2012/04/26/a-stranger-in-strange-lands/. Feb. 6, 2013.

Marion, P. 1993a. "Scénario de bande dessinée: La différence par le média ». Études littéraires 26 (2): 77-89.

Marion, P. 1993b. Traces en cases. Louvain-la-Neuve: Academia.

Mikkonen, K. 2008. "Presenting Minds in Graphic Narratives". Partial Answers 6 (2): 301-321.

Muehrcke, P. C. 1978. Map Use: Reading, Analysis, and Interpretation. Madison: JP Publications.

O'Neill, P. 1994. Fictions of Discourse: Reading Narrative Theory. Toronto: University of Toronto Press.

Round, J. 2010. "Be Vewy, Vewy Quiet. We're Hunting Wippers: A Barthesian Analysis of the Con-struction of Fact and Fiction in Alan Moore and Eddie Campbell's From Hell". Ed. Joyce Goggin and Dan Hassler-Forest. The Rise and Reason of Comics and Graphic Literature: Critical Essays on the Form. Jefferson: McFarland. 188-201.

Sacco, J. 2012. "Preface: A Manifesto, Anyone?". Journalism by Joe Sacco. New York: Metropolitan. xi-xiv.

Verano, F. 2006. "Invisible Spectacles, Invisible Limits: Grant Morrison, Situationist Theory, and Real Unrealities". International Journal of Comic Art 8 (2): 319-329.

Versaci, R. 2007. This Book Contains Graphic Language: Comics as Literature. New York: Continuim.

\section{Arborescences}


Vivan, I. 2000. "Geography, Literature, and the African Territory: Some Observations on the Western Map and the Representation of Territory in the South African Literary Imagination". Research in African Literatures 31 (2): 49-70.

Wolk, D. 2007. Reading Comics: How Graphic Novels Work. Cambridge, MA.: DaCapo Press.

Wood, D. 1992. The Power of Maps. New York: Guilford. 